\title{
The Judiciary in Illiberal States
}

\author{
Zdeněk Kühn ${ }^{1}$ \\ ${ }^{1}$ Judge, Supreme Administrative Court, Brno, Czechia \\ Corresponding author: zdenku@seznam.cz
}

(Received 30 September 2021; accepted 30 September 2021)

\begin{abstract}
The Article deals with the actual functioning of the judicial power and the limits of its independence facing an illiberal or authoritarian state. The Article offers a skeptical analysis of the past and especially of the judiciary's future in Central Europe, with a primary focus on Czechia and Slovakia. After a brief excursion into the times before the installment of communist regimes in the late 1940s, attention shifts to the development of the judiciary during the three decades after the fall of communist rule. In this context, the Article deals with different models of administration of the judiciary and shows how they can function in normal democracy and under the conditions of emerging authoritarianism. It also characterizes different perspectives on the judiciary in common law and continental law and posits different capacities of judges to resist authoritarians in various legal cultures. Finally, it sketches future prospects and attempts to define the typology of judiciary models in authoritarian and totalitarian states.
\end{abstract}

Keywords: System of law; constitutional courts; judiciary; role of judiciary in defense of the legal system; authoritarianism; common law and civil law; continental law

\section{A. Introduction}

The specter of an authoritarian state has resurfaced over the last decade and not only in Central Europe. When a state embarks on the path towards authoritarianism, it need not necessarily abandon democracy as such but might instead begin circumventing the separation of powers. Indeed, in the eyes of many authoritarians, the separation of powers, the principle of checks and balances, as well as the rule of law itself, excessively "restricts" the enforcement of general people's will, mediated by the political goals pursued by the parliamentary majority which is currently in power, and has last been elected. ${ }^{1}$ In this understanding, democracy is based on a populist ideology "which considers society to be ultimately separated into two homogenous and antagonistic groups: 'the pure people' and 'the corrupt elite,' and argues that politics should be an expression of the volonté générale [general will] of the people."

Zdeněk Kühn, Professor of jurisprudence at the Faculty of Law of Charles University and Judge of the Supreme Administrative Court in Brno. All opinions presented in this Article are personal opinions of the author rather than of the institutions where he works. The Article was written with the support of Czech Science Foundation Project No. 19-10723S: "What unifies current law and what fragments it in terms of legal theory and case law?"

${ }^{1}$ For more details on the theory of an authoritarian state, $c f$. Stephen Haber, Authoritarian Government, in THE OXFORD Handbook of Political Economy 693 (D. A. Wittman \& B. R. Weingast eds., 2008). Classical works dealing with the theory and practice of authoritarian and totalitarian states are those of Juan Linz. Cf. e.g., Juan Linz, AUTHORITARIAN AND Totalitarian Regimes (2000).

${ }^{2}$ This is how Cas Mudde defines populism in his influential work. See Cas Mudde, The Populist Zeitgeist, 39 GovernMENT AND Opposition 541, 543 (2004). For the most recent contribution, see POPUlist Constitutionalism AND ILLIBERAL Democracies (Martin Belov ed., 2021).

(C) The Author(s), 2021. Published by Cambridge University Press on behalf of the German Law Journal. This is an Open Access article, distributed under the terms of the Creative Commons Attribution licence (https://creativecommons.org/licenses/by/4.0/), which permits unrestricted re-use, distribution, and reproduction in any medium, provided the original work is properly cited. 
The concepts of the rule of law, constitutionalism, and "liberal democracy" are based on subordination of the majority's will in power to higher rules that must not be breached even by the current parliamentary majority. It is, however, hardly compatible with populist democracy, which presents itself as a pure democracy, not restricted by any influential groups. Indeed, the populists see the role of a constitutional state and the rule of law elsewhere. Rather than protecting certain general rules by non-political institutions such as constitutional and general courts, and various independent administrative authorities, such a state-in their opinion-seeks protection of certain controversial and, in their very nature, political values enforced by the "elites" against the general will. Populists will tend to agree on this most general perspective, although their views might differ regarding the specific values the elites are purportedly trying to protect. What those values are will depend on the populists' political preferences. For example, from a left-wing viewpoint, the elites might be pursuing their interests in terms of class and property, while on the other extreme, elite objectives might pertain to various sexual or national minorities or refugees, that is, groups that elites allegedly want to abuse to destroy the nation's "healthy core."

In the long run, the notion of democracy without the rule of law must necessarily limit democracy as such. Indeed, given populism's diminished emphasis on compliance with legality, nothing prevents key political actors from holding on to their power even by means that impair free competition of political forces. This may include, for example, taking control of public-service media and, eventually, the media environment as such, of the public administration, and last but not least, of the state attorney's offices and courts. Elections then become illusory. Voters have no realistic choice among several options, either because there is no fair political competition or because there is no independent institution that could guarantee a proper course of elections. It could be argued that because the courts have completely lost their competence in electoral issues or because electoral courts are subordinated to those currently in power.

This Article will analyze the actual functioning of the judicial branch and its possible independence while facing a new wave of global populism and the reemerging specter of an authoritarian state with a particular emphasis on the Czech experience. Some might argue that Europeans are trying to re-experience their history in a different form. At a time when the degree of populism is increasing and the confidence in institutions of the classical democratic state, governed by the rule of law, is decreasing, this Article asks how the judiciary can take a stand in this historical test. In this sense, this Article offers as a skeptical analysis of the past and especially of the judiciary's future (not only) in Central Europe.

This Article begins with a brief historical excursion into the time before the late 1940s, when the communist rule was installed in Central Europe, and then to the first three decades following the fall of communist rule. While doing so, this Article will deal with different models of administration of the judiciary and show how they can function in a normal democracy and under the conditions of emerging authoritarianism. Finally, this Article will venture to look into the future and try to define a typology of various models of how the judiciary functions in authoritarian and totalitarian regimes.

\section{A. Central European Judiciary from a Historical Perspective}

What is often forgotten are the historical roots of the Central European judiciary. ${ }^{3}$ In the second half of the $19^{\text {th }}$ century, the Habsburg Monarchy transformed the previously existing bureaucratic judicial apparatus into an independent judicial branch. In this system, judges were expected to make their decisions in the name of the Emperor, and any political attacks aimed against the judiciary were thus effectively avoided as they would simultaneously go against His Majesty itself.

\footnotetext{
${ }^{3}$ See Zdenek Kühn, The Judiciary in Central and Eastern Europe: Mechanical Jurisprudence in TRANSFORMATION? 1-20 (2011).
} 
While the judiciary was administered by the relevant ministry, judges were nevertheless protected by their special relationship to the emperor in whose name they pronounced their decisions. ${ }^{4}$

After the Habsburg Monarchy was overthrown in October 1918, the judges in many successor states were quick to understand that a republican judiciary would operate quite differently than a judicial system established in a constitutional monarchy. Ambiguities regarding the role of the judiciary in a system of separated powers were reflected in the position of the judiciary in the individual European countries between the World Wars.

It can be stated that the position of judiciary in Central Europe deteriorated after 1918 as compared to the period before 1914. Indeed, new republican governments conceived the system of separated powers as a parliamentary government with a dominant role of political parties and their leaders. Moreover, in many countries, such as Poland and Austria, the initial promising democratic developments already degenerated into various authoritarian regimes in the $1920 \mathrm{~s}^{5}$ In such a system, it was desirable to exercise relatively unlimited control over the judiciary in situations where it had proven not to rule according to the will of the elites in power. $^{6}$

The same was true in democratic Czechoslovakia following the year 1918. Certain basic guarantees of the judiciary's independence were put on hold at the time of the "First Czechoslovak Republic," including the principle of irremovability of judges and the prohibition on relocating a judge without his consent. ${ }^{7}$ Politicians in parliament and at government posts also showed an appetite for directly influencing judicial decision-making and even attempted to remove the presidents of courts that had been making, in the politicians' view, inadmissible rulings. Such attacks are often related to decision-making on controversial aspects of laws governing language and the position of the "Czecho-Slovak nation" in relation to the German minority in general. ${ }^{8}$

This is why the celebrations of the tenth anniversary of the Republic in 1928 were somewhat bitter for Czechoslovak judges. This is how one judge, long-time editor-in-chief of the professional judicial journal, recalled the historical Austrian judiciary in 1928 which guaranteed judges a better position and more independence than the new Republic:

It is a generally known fact that judiciary was one of the things the Austrian Monarchy could pride itself on. The Austrian Code of Civil Court Procedure was rightfully admired abroad for its modernity, while the work of Austrian judges, in spite of the often obsolete substantive law, both civil and criminal, kept up with the times, and especially their moral integrity and incorruptibility was generally acknowledged and recognized. ${ }^{9}$

\footnotetext{
${ }^{4}$ Staatsgrundgesetz über die richterliche Gewalt [Constitutional Law on Judicial Power] Reichsgesetzblatt [RGBL], No. 144/ 1867, https://www.ris.bka.gv.at/Dokument.wxe?Abfrage=BgblAlt\&Dokumentnummer=rgb1867_0144_00398 (Aust.). It is one of the first laws constituting the 1867 "December Constitution," stating in its first Article that "all the judicial powers in the state shall be exercised in the name of the Emperor; judgements shall be rendered in the Emperor's name."

${ }^{5}$ It should be noted that this is precisely why Czechoslovak judges acknowledged that the situation in other Central European countries was much worse than in Czechoslovakia. Cf. Po Ochraně Soudù [On the Protection of Courts], 68 PRÁVNíK 31 (1929) (exploring the political influencing of the judiciary in the Weimar Republic). See also Úték ze Soudních Služeb [Escaping from Judicial Services], 5 SOUdCOvsKé LISTY 57 (1924) (describing the situation in postWorld War I Austria). Cf. George Papuashvili, Post-World War I Comparative Constitutional Developments in Central and Eastern Europe, 15 INT'L J. ConsT. L. 137 (2017).

${ }^{6}$ For more details, including numerous quotes from other literature, see Kühn, supra note 3; MiCHAL PRINC, SOUDNICTVÍ V ČESKÝCH ZEMíCH V LETECH 1848-1938 [The Judiciary in the Czech Lands from 1848-1938] (2015).

${ }^{7}$ In this respect, see, e.g., PRINC, supra note 6, ch. VIII. 4.

${ }^{8}$ In this respect, see the following contemporary articles. Povážlivý Zjev [Disturbing Phenomenon], 67 PRÁVNíK 261-62 (1928), or an article published by a Judge of the Czechoslovak Supreme Court, for example, Václav Cícha, Kritika Nejvyššího Soudu v Parlamentě [Criticism of the Supreme Court in the Parliament], 69 PRÁVNí 106 (1930).

${ }^{9}$ Karel Krcha, Soudnictví Před Deseti Llety a Dnes [The Judiciary Ten Years Ago and Now], 67 PrÁVNík 596-603 (1928).
} 
In the public debate, the independence of judges during the First Czechoslovak Republic in the Habsburg Monarchy was compared to the situation prevailing in the new successor countries. ${ }^{10}$ They spoke about a crisis of judiciary, "which is not remembered even by the eldest of our colleagues." 11 They also openly criticized the political influencing of judges and attempts to remove the presidents of courts, the dire financial and material conditions, ${ }^{12}$ and the constant interference by the parliament and the executive branch with judges' remuneration. ${ }^{13}$

With the judiciary impaired by repeated state interference and constant tampering with judges' salaries, corruption eventually emerged to the extent that was completely unknown to the judges during the times of the Austrian Empire. The first corruption case broke out among judges in the late 1920s. This caused a considerable uproar at the time because something like that had been unimaginable just ten years earlier, according to the general opinion. ${ }^{14}$

The weakened judiciary then lived through the Protectorate and, in the period from 1945 to February 1948, also through the decay associated with court trials against Nazi collaborators and traitors, which often merely imitated a fair trial. Similar to the First Republic (1918-1938), the politicians of the short-lived Third Republic (1945-1948) did not hesitate to openly interfere with court decisions if they were not to their liking. For example, during a speech given at a rally in August 1946, the new Prime Minister, Klement Gottwald, who later became the first communist president of Czechoslovakia, harshly criticized certain rulings made by the Supreme Administrative Court which had been asked to apply the "nationalization" decrees. At a time when the Czechoslovak Communist Party still exercised some self-restraint, he clearly showed how he understood the notion of "judicial independence". In his opinion, the "independence" of a judge did not amount to independence of the law and government: "A judge must rule according to the law, while taking account of the public sentiment and opinion of the government."15

After the communist coups of the late 1940s, a debilitated judiciary was unable to stand up to the imposition of communist rule. The judiciary was therefore taken over quickly and smoothly. For instance, some ten percent of the then-two thousand Czechoslovak judges were soon excluded from the judiciary as they were considered "hostile and politically unreliable."16

The transformation of the judiciary at the beginning of communism could not be equated to a mere purge. About one-half of the judges' posts in Czechoslovakia ${ }^{17}$ were not filled after World War II. At the end of the 1940s already the judiciary was fundamentally reorganized in all Central European countries; a number of new judges were assigned to judicial positions, including graduates of crash courses in law at "worker's law schools" at the beginning of the Stalin era. Nonetheless, in the mid-1950s, almost one-half of the Czechoslovakian judges of the pre-communist era were still in office. ${ }^{18}$ The power of the newly arrived "people's" judges was not owing to the fact that, ten years after the end of the war, they would outnumber their older colleagues, but rather that they controlled key positions in the judiciary, including the posts of court presidents. ${ }^{19}$

\footnotetext{
${ }^{10}$ See Václav Brožovský, Stav Našeho Soudnictví [State of Our Judiciary], 70 PrÁvNík 41-51 (1931).

${ }^{11}$ Do Nového Roku [Into the New Year], 2 Soudcovské LISTY 1, 2 (1921). On a similar note, see unsigned article (authored probably by Karel Krcha) Neodvislost Soudcovská [Judicial Independence] 4 SoudCovsKé LisTY 12-13 (1923).

${ }^{12}$ Response of the judicial organization to the Ministry of Justice, with a note from Václav Hora, 67 PRÁVNí 14-19 (1928).

${ }^{13}$ Karel Krcha, Nespokojenost Soudců [Judges’ Dissatisfaction] 6 SoudcovsKé LIsTy 85 (1925).

${ }^{14}$ See Vážné Memento! [Serious Warning!] 68 PRÁVNíK 318 (1929) (describing probably the first case of corruption among the Czech judiciary in the 20th century).

${ }^{15}$ Klement Gottwald, Za Socialistický Stât, Za Socialistické Právo [For a Socialist State, For Socialist Law] 79 (1950).

${ }^{16}$ Statement by K. Klos, a former Deputy Minister of Justice, On the state of affairs in justice in 1948-1952 (Apr. 1, 1963), in: Československá Justice V Letech 1948-1953 v Dokumentech. Díl II. 72 [Czechoslovak Justice in 1948-1953 in Documents. Volume II.] (Office for the Documentation and Investigation of the Crimes of Communism: Prague, 2004).

${ }^{17}$ Eliška Wagnerová, The Position of Judges in the Czech Republic, in Systems of Justice In Transitional CENTRAL European EXPeriences SinCe 1989163 (Jiř́ Přibáń, Pauline Roberts \& James Young eds., 2003).

${ }^{18} I d$.

${ }^{19}$ In general, $c f$. Ota UlČ, The Judge In a Communist State. A View From Within (1972).
} 
For example, in 1951, three years after the communist coup, 55 out of the total number of 280 graduates of five courses at the "worker's law school" were in the position of presidents of the district courts, one was at the Supreme Court, and 115 were district prosecutors. ${ }^{20}$

\section{B. Model of Judicial Administration}

The current Czech model of administration of the judiciary is functionally and conceptually linked to the original Austrian model created at the end of the $19^{\text {th }}$ century, following the adoption of the Austrian December Constitution in 1867. Under Section 73 of the 1896 Act, courts and state attorney's offices were:

[S] ubordinate to the Minister of Justice in terms of administration of the judiciary. Within the exercise of this administration, they may ask for collaboration from officials who are subject to their supervision." This "right of supervision" included "the authorization to supervise whether the relevant work is being carried out properly, and guide the courts and the state attorney's offices to perform their duties and remedy any defects found or make a notice thereof to a superior court, which may order the necessary measures. ${ }^{21}$

While the Austrian model left judges in a somewhat "apolitical" bubble protected by the Emperor's majesty, the situation rapidly changed after 1918. That is when politics fully expanded to the judicial sphere. As I stated above, the Czechoslovakian judges in the 1920s and 1930s were very critical towards the judicial system. The same was true of the model of judicial administration. In this context, the judges expressed highly negative views of the judicial administration carried out by the Minister of Justice. ${ }^{22}$ Indeed, most of these critical contributions published during the times of the First Republic seem strikingly relevant at present. An apex of these debates is represented by the contributions of Karel Krcha who wrote the following words at the end of the 1930s:

Only then will the judges be actually and truly independent if they will be certain that decisions on their lives and careers will not be made by the judicial administration without any control but will rather be arranged in a manner that limits as much as possible the possibility of partisan and non-substantive decisions on these issues.... Suggestions that the judges would then build a state of their own, that there would be a danger of abuse of their absolute independence for the exercise of government, that parliamentary responsibility of the Ministry of Justice would become illusory, etc., are mostly unfounded and immaterial because what we intend to achieve is merely a limited autonomy within the Constitution under the control and with collaboration of the judicial administration, while disciplinary and criminal legislature would provide sufficient protection against judges lacking merits [... If we consider that nowadays, the Minister of Justice can be even a person without any moral scruples, who places the welfare and benefit of the state above independence of judges, and who can actually persecute and terrorise a judge at his own discretion in order to achieve certain results that might possibly be at stake, we come to understand that this is where there is a danger of a political influence on either all the judges or a certain individual judge. ${ }^{23}$

\footnotetext{
${ }^{20}$ Wagnerová, supra note 17 , at 163 .

${ }^{21}$ The Judicial Organization Act, No. 217/1896 Sb. (issuing regulations on appointing judges and courts' internal structure and rules of procedure) (Czech).

${ }^{22}$ See e.g., Několik Poznámek ke Schůzi Československých Soudců [Several Remarks on the Meeting of Czechoslovak Judges], 59 PrávNík 68 (1920); Václav Hora, Stav Našeho Soudnictví [The State of Our Judiciary], 66 PrÁVNík 697 (1927); Karel Krcha, Ne Odpolitisování Soudců, ale Soudní Správy [Not Depoliticization of Judges, but Rather of the Judicial Administration], 18 Soudcovské LISTY 53 (1937); Karel Drbohlav, Justice a Její Administrativa [Judiciary and its Administration], 18 SoudCOVSKÉ LISTY 83 (1937).

${ }^{23} \mathrm{Krcha}$, supra note 22 , at 55.
} 
These words about the "person without any moral scruples" were prophetic. One reason it was so easy to take control of the judiciary after the communist takeover in the late 1940s was that the communist regime was very efficient in taking advantage of the valid laws governing the administration of the judiciary. Those laws enabled the new totalitarian power to assume complete control of the entire judicial system over a period of several months without actually transforming the system in any significant way. Moreover, it was sufficient for the Ministry of Justice to control the key positions of court presidents as these posts were endowed with sufficient powers inside the courts-for example, allocating the court agenda or appointing judges to decide on individual cases.

The communist legislature adopted the Austrian, and the follow-up First-Republic, concept of judicial administration. According to the mentioned Act, it was the task of judicial administration to take care of everything that the courts needed for the proper exercise of justice, especially in terms of personnel, organization, finances, economics, planning, and training. The Minister of Justice or bodies authorized by the Minister monitored how the courts performed their tasks and complied with socialist legality in their activities. Based on the Act's wording, only decisions that had entered into legal force could be subject to supervision over court decision-making. ${ }^{24}$ The legislation on the judiciary also empowered the Ministry of Justice to monitor court activities, make the relevant generalizations, and propose that the Plenum of the Supreme Court issue guidelines for the correct interpretation of laws and other legal regulations. Within the performance of the State administration of courts, the Minister also became authorized to conclude that a case which had already been decided by a final court ruling had been, in fact, assessed incorrectly, and therefore gave the Minister an incentive to file a complaint about violation of the law. ${ }^{25}$

The Second World War and the subsequent four decades of communist rule put a halt to the entire debate on the administration of the judiciary, ${ }^{26}$ merely for it to return to the public space after 1989. However, the lack of reflection on the Western European experience of the four postwar decades continues to fundamentally affect the level and nature of discourses regarding the administration of the judicial branch.

Unfortunately, it thus remains the fact that the problem of "state administration" of the judiciary intertwines all the regimes that existed in the territory of Czechoslovakia in the $20^{\text {th }}$ century and also had to be dealt with repeatedly by the Constitutional Court in the $21^{\text {st }}$ century. The system of "state administration" of the judiciary is still basically unchanged-for example, even today, the Minister of Justice can ask the Supreme Court to issue its abstract opinion on a certain matter. ${ }^{27}$ The only exception in this respect-in terms of discontinuity-remains the abolished authority of the court's president to chair any chamber in the given court and thus, directly influence the decision of any case heard before that court. ${ }^{28}$

Although the position of Minister of Justice vis-à-vis the judiciary remains, in theory, very strong even at the beginning of the third decade of the $21^{\text {st }}$ century, the reality of Czechia is somewhat more complicated. "Law in action" works in favor of judicial independence. ${ }^{29}$ The powers within the justice administration are divided among politicians, presidents of the regional and

\footnotetext{
${ }^{24}$ Section 38 of Act No. 66/1952 Sb. (on organization of courts) (Czech).

${ }^{25}$ Section 35 of Act No. 36/1964 Sb. (on organization of courts and election of judges) (Czech).

${ }^{26}$ Probably the last contribution to the entire debate was published by one of its most engaged participants, Judge Karel Krcha, as late as in November 1939. See Karel Krcha, Soudcovská Neodvislost v Protektoráté [Independence of Judges in the Protectorate], 20 Soudcovské LISTY 325 (1939). The month of November 1939, the third month of the World War II in the German Protectorate of Bohemia and Moravia, was the swan song for any further considerations regarding independence of the judiciary. As a matter of fact, the censor marked the article as prohibited to quote in any way.

${ }^{27}$ Section 123 (3) of Act No. 6/2002 Sb. (on the courts, judges, lay judges, and state administration of courts and on an amendment to certain other laws) [The Judiciary Act] (Czech).

${ }^{28}$ See Michal Bobek, The Administration of Courts in the Czech Republic-In Search of a Constitutional Balance. 16 EuR. PuB. L. 251 (2010); Samuel Spáć, Judiciary Development after the Breakdown of Communism in the Czech Republic and Slovakia, 9 CEU POL. SCI. J. 234 (2014).

${ }^{29}$ For a similar argument, see David Kosař, Politics of Judicial Independence and Judicial Accountability in Czechia: Bargaining in the Shadow of the Law between Court Presidents and the Ministry of Justice. 13 EUR. CONST. L. REV. 96 (2017).
} 
higher courts, three thousand judges, and the ministerial bureaucracy. The skeptical opinion expressed by one former Minister of Justice (in office 2015-2018) is quite characteristic in this regard. After leaving his office he stated that, in reality, "this is a brilliant system where power has disappeared completely." ${ }^{30}$

It thus seems that the Czech system of judicial administration can work well under conditions of a constitutional state based on a certain political culture, which respects certain basic rules of the relationship between the judiciary and the executive branch, and the relationship between the judiciary and general politics as such. Under optimal political conditions, the Czech "ministerial" system of judicial administration can even influence the judiciary in a positive way. The participation of several actors in the formation of the judiciary and a strong role reserved for democratic politics within the administration of courts can reduce the natural tendencies of the continental judiciary towards "sheathing itself," that is closing off the judiciary into a world of incomprehensible and empty legal formulas. When the Czech judiciary is compared with its Slovak counterpart, one can even say that the conservative nature of Czech politics, which has not introduced the "European" model of the supreme council of magistracy, has paradoxically left Czech courts in a better shape than in Slovakia. ${ }^{31}$

The inherent problem associated with the Czech model of judicial administration is, thus, probably more closely linked with the fact that it leaves the courts and judges defenseless against politicians who might intend to retrieve the power which has "disappeared." 32 Such steps would be difficult to negotiate in a "liberal" democracy model, based on separation of powers and on generally shared values of checks and balances. However, the same steps are much easier in a nonliberal model, which is heading towards authoritarianism. In this very model, the Minister of Justice could be "a person without any moral scruples," 33 who will change the rules of the game.

The Czech judiciary has thus historically been compromised by the fact that the "ministerial" model of judicial administration functions well only under favorable political conditions-the period from the 1870s to the summer of 1914, the first three decades after 1989. However, when it eventually clashes with politics, the judiciary loses much of its strength and is not capable of playing its role as the one who protects legality and law. The recent Polish experience of merging the positions of the Minister of Justice and the General Prosecution in one, and the executive assault on the judiciary provide a good warning in this respect. ${ }^{34}$

\section{Challenges and Temptations in the Czech Judiciary After 1989}

It can perhaps be asserted that after 1989, the Czech judiciary has not faced, thus far, any fundamental attack aimed against the democratic values and principles of the Czech state. It has remained far from the Polish or Hungarian scenarios of the 2010s.

${ }^{30} \mathrm{Mr}$. Robert Pelikán in the interview, after he had left the office of Minister of Justice, mentioned, inter alia:

"Everything is actually more complicated and anyone who seems to hold some power in fact lacks any because he is dependent on what others prepare for him. And such other persons depend, in turn, on someone else. This a brilliant system where power has disappeared completely. Things eventually get done in some way and this creates the impression that someone is in charge of something, but no one can, in fact, fundamentally change or influence anything in the system. In the end, when you think about it all, this is damn' good because it gives the country stability as well as certainty that no one will be able to abuse his position in a way that could cause really serious problems to citizens."

See the first post-ministerial interview with Robert Pelikán, magazine INFO.CZ, (Nov. 13, 2018).

${ }^{31} C f$., in this respect, the excellent work by David Kosař, Perils of Judicial Self-Government In Transitional Societies (2016). See also Samuel Spáč, Katarína Šipulová \& Marina Urbániková, Capturing the Judiciary from Inside: The Story of Judicial Self-Governance in Slovakia. 19 GERMAN L. J. 1741 (2018); David Kosař \& Samuel Spáč, Post-communist Chief Justices in Slovakia: From Transmission Belts to Semi-autonomous Actors? 13 Hague J Rule L. 107 (2021).

${ }^{32}$ See INFO.CZ, supra note 30.

${ }^{33}$ See the text accompanying footnote no. 23.

${ }^{34}$ Fryderyk Zoll \& Leah Wortham, Judicial Independence and Accountability: Withstanding Political Stress in Poland, 42 FORDHAM INT'L L. J. 875, 891-92 (2019). 
Even the notorious judgment regarding the "unconstitutional constitutional" Act of 2009, the Melćák case, in which the Constitutional Court annulled the constitutional act on shortening the term of office of the lower house of the parliament because it was enacted as an ad hoc law, ${ }^{35}$ was more like the proverbial sledgehammer that is used to crack a nut than a real defense of the key values of the rule of law. ${ }^{36}$ At the same time, it is typical of the first two decades of the existence of the Czech state and the then prevailing liberal consensus on the rule of law that voices suggesting that this Constitutional Court judgment should be ignored were in the vast minority. In substance, the entire political elite, even if gnashing their teeth, accepted the Melčák judgment. ${ }^{37}$

Thus, rather than openly ignoring court rulings, some politicians have disquietingly been trying to influence the courts in a covert manner. The scandal that broke out in early 2019 regarding meetings of Czech President's Chancellor with the former President of the Supreme Administrative Court and with some of the justices of the Constitutional Court, as well as the overt attempts to influence judicial decisions, might thus be the proverbial tip of the iceberg, rather than a rare and unique phenomenon. ${ }^{38}$

At the same time, a shift can be observed after 1989 towards the fundamental strengthening of the judiciary, shifting from the timid "Cinderella" to an independent "third" branch of power in the state. As late as in 1999, removal of five regional court presidents by the Minister of Justice, Otakar Motejl, did not cause any substantial uproar, ${ }^{39}$ and even the presidents themselves did not contest the Minister's decision in any way. It can be stated with a certain degree of exaggeration that ten years after the fall of the communist regime, the court presidents acted as obedient officers of the government in relation to their superior authority.

However, six years later, the President of the District Court for Prague-West defended herself against her removal by the Minister of Justice by filing a lawsuit with an administrative court, which eventually annulled the Minister's decision. ${ }^{40}$

A real revolution in the constitutional concept of the position of the court presidents was caused in 2006 by an attempt of the Czech President, Václav Klaus, to remove the Supreme Court President, Iva Brožová. At the time, the Constitutional Court strictly rejected the executive branch's power to remove court officers and declared it unconstitutional, explaining, "The Constitutional Court emphasizes that the principle of 'who appoints also removes' is inherent to the system of government. Indeed, government is characterized by the exercise of public authority, i.e. exercise of executive power in hierarchical relations, i.e. relations of superiority and subordinacy." However, the performance of duties of a court officer is not a classical exercise

\footnotetext{
${ }^{35}$ Nález Ústavního soudu ze dne 10. záři 2009 [Judgement of the Constitutional Court of Sept. 10, 2009], No. Pl. ÚS 27/09 (Czech).

${ }^{36}$ See Yaniv Roznai, Legisprudence Limitations on Constitutional Amendments? Reflections on The Czech Constitutional Court's Declaration of Unconstitutional Constitutional Act, 8 ICL J. 29-57 (2017).

${ }^{37}$ The then-incumbent head of the Czech Social Democratic Party, Paroubek, and President Klaus expressed the strongest opposition. Paroubek denoted the judgement as unconstitutional. See Respekt, či prekročení pravomocí? Politiky verdikt soudu rozdělil. [Respect or excess of powers? The court verdict divided the politicians.], IDNES.cz, (Sept. 10 2009), https://www.idnes. cz/zpravy/domaci/respekt-ci-prekroceni-pravomoci-politiky-verdikt-soudu-rozdelil.A090910_165242_domaci_bar. The President of the Republic even called for a major restriction of the Constitutional Court's powers. Klaus: Ústavní soud vědomě prohlubuje krizi, je třeba mu určit nové pravomoce [Klaus: The Constitutional Court is knowingly deepening the crisis; its powers need to be redefined] Novink.CZ, (Sept. 10, 2009), https:/www.novinky.cz/domaci/clanek/klaus-ustavni-soud-zamerne-prohlubuje-krizijeho-pravomoci-se-musi-zmenit-40236383. However, even President Klaus did not plea for ignoring the judgement at the time.

${ }^{38} \mathrm{Cf}$. Kundra \& Procházková, Pozor, volá Mynář. Jak se pravá ruka prezidenta snaží ovlivnit soudce. [Attention! Mynář calling. How a President's sidekick has been trying to influence judges], ResPeKT, (Jan. 30, 2019) https://www.respekt.cz/ tydenik/2019/2/vola-mynar.

${ }^{39}$ The only strong voice raised against this step taken by the Minister of Justice in 1999 was that of the then- President of the Supreme Court, Eliška Wagnerová. Cf. Pravým důvodem odvolání soudců je žrejmě jejich minulost [The Real Reason behind the Removal of Judges is Apparently their Past], IDNES.cz (Mar. 17, 1999), https://www.idnes.cz/zpravy/domaci/pravymduvodem-odvolani-soudcu-je-zrejme-jejich-minulost.A_990316_231932_domaci_pch.

${ }^{40} J u d g e m e n t$ of the Municipal Court in Prague of 24 June 2005, Ref. No. 5 Ca 37/2005-42 (Czech).
} 
of government or state administration. The office of the court president is inseparable from the office of a judge as the given person cannot be in a dual legal position, of a court president as a government officer, on the one hand, and that of a judge, on the other hand. Thus, the attributes of independence of the judicial branch must also apply to presidents of the courts'. The Constitutional Court concluded:

The principle of separation of the judicial and executive branches under the current constitutional regulation and in accordance with the standards that follow from the European and international environment implies the requirement that an officer of the judicial branch be only removable through a procedure taking place within the judicial branch itself. ${ }^{41}$

In 2006, the Constitutional Court thus fundamentally strengthened judicial branch's independence within the Czech constitutional system. Indeed, the Achilles' heel of judicial independence in the continental legal system is the strong position of courts' presidents. ${ }^{42}$ As the power vested in court presidents in the bureaucratic model of the continental judiciary allows interference with the exercise of judicial functions as such, For example: By approving work schedules, including assigning a certain type of agenda to certain judges, not approving an excess of the statutory deadline for drawing up the written counterpart of a decision, the possibility of abusing disciplinary motions against disobedient judges The Czech Constitutional Court thus simultaneously ruled out, pro futuro, any arbitrary removal of courts presidents, as had occurred in Poland in 2017, where the Minister of Justice removed as many as 149 of the total 730 presidents and vice-presidents of courts during the first six months of approval of the new Judiciary Act. ${ }^{43}$

\section{The Judiciary in the Common Law and Civil (Continental) Law Models and Genuine Possibilities of Halting the Onset of Authoritarianism}

Comparative law provides some reasons to believe that in the long term the judiciary, based on the continental (civil) model of law, is less resistant to authoritarian regimes than a judiciary functioning in the environment of common law. The two judicial systems are substantially different, in both institutional and personal terms. While the mentality of common-law judges is based on the tradition of independence, which has been formed for centuries, the mentality of the continental judiciary has been shaped along the bureaucratic ideal.

The continental judiciary is based on the hierarchical and bureaucratic ideal of state power. In this model, judicial system rests on the principles of strict hierarchy, lack of personality in formal norms of law, and logical legalism. Judges are trained legal professionals. Judicial corps existing under this ideal of state power resemble bureaucracy, both in their style and thinking, and in their decision-making. Judicial decisions are "nameless," drafted on behalf of the court as an institution, rather than in the name of every single judge as in common law. The form of reasoning adheres to a single "ideal" style; any excessive personality or originality of style is undesirable as it is not the judge, but rather the court that decides. As a matter of fact, this is the reason why courts have not been permitted to publish potential dissenting opinions in the system of continental law-the court as an institution speaks in a single voice rather than as a cacophony of voices of individual judges.

\footnotetext{
${ }^{41}$ Nález Ústavního soudu ze dne 11.07.2006 (ÚS) [Decision of the Constitutional Court of July 11, 2006], No. Pl. ÚS 18/06 (Czech). See Michal Bobek, The Administration of Courts in the Czech Republic -In Search of a Constitutional Balance. 16 Eur. PuB. L. 251 (2010).

${ }^{42} C f$. Adam Blisa \& David Kosař, Court Presidents: The Missing Piece in the Puzzle of Judicial Governance. 19 GERMAN L. J. 2031 (2018).

${ }^{43} \mathrm{Cf}$. The Response to the White Paper Compendium on the Reforms of the Polish Justice System, IUSTITITIA https:// www.iustitia.pl/informacje/2172-re-\%20sponse-to-the-white-paper-compendium-on-the-reforms-of-the-polish-justice-systempresented-by-the-government-of-the-repub-\%20lic-of-poland-to-the-european-commission.
} 
It is characteristic that the judicial corps is established in this system as a "professional" (career) model. Judges are selected in an administrative manner at the beginning of their professional careers; their appointment follows relatively soon after graduating from law school. The choice of future judges is a relatively technical exercise, examining the candidates' ability to conduct the judicial procedure and reflecting their capacity, especially based on their school grades and various tests. Given the apolitical nature of selecting candidates for the judicial office, a judge him or herself is also primarily apolitical and, in substance, an indistinct figure.

The ideal of the continental judiciary supports conformity: already the way young lawyers get into the judiciary - several years of preparatory service in the judiciary itself, where young lawyers are being prepared for their judicial careers by older experienced judges, and thus identify themselves with internal values of the judiciary. Likewise, the way they are promoted-typically, those judges whose judgments are rarely annulled at appellate instances get to be promoted to higher courts. On one hand, this is clearly dangerous for the exercise of judicial power in authoritarian regimes: an ambitious judge longing for a good career at a higher court will be motivated to appeal to the government, especially if the judiciary is administered by a ministry.

On the other hand, common law courts are far from a strictly bureaucratic and hierarchical system from the institutional perspective. Judges are organized in the judicial system in that they are interconnected, not through a fixed hierarchical structure, but rather by shared ideas and values. Damaška denotes such a judiciary as a "coordinated model." 44 The judiciary is composed of judges who are not specialists and, in the purest form, they were not even graduate lawyers until the $19^{\text {th }}$ century. In this system, judges seek justice in individual cases rather than justice by law comprised of formalized sources. They are very strong personages who consider substance and values in their decisions. Primarily, however, there is no career temptation: As judges in the common law system are rarely promoted to courts of higher instances, there is no pressure for them to conform.

Many judges have their own style of legal argumentation or writing judgments; originality of style is beneficial and shows judge's personality because, after all, the judge is the main actor in the development of law. This is why, since time immemorial, the right of every judge to state his or her own reasons for the given ruling has been a part of the English judicial procedure. The choice of such judges is typical of a political model emphasizing political criteria and preferring judges with life experience, as in this model, the knowledge of law presupposes the knowledge of life primarily. ${ }^{45}$ Judges are appointed, or even elected in some states of the USA, at an older age, based on a comprehensible and long professional history. ${ }^{46}$ Of course, such a system suffers from a number of maladies but has historically created a strong and independent judiciary.

The above is not just some abstract theory unsupported by empirical experience. It is true that, in Europe, judges trained in the common law culture have not encountered an authoritarian regime. However, a true reservoir for comparison, a real comparative laboratory, is the African judiciary. Countries of both the continental (civil law) system, former French, Italian, Portuguese, Spanish and Belgian colonies, and the common law system, former British colonies, eventually fell to various dictatorships. It is true that the courts in neither of these systems were capable of preventing the manifestations of dictatorship in the long term. However, the degree of

\footnotetext{
${ }^{44}$ Mirjam DamašKa, The Faces of Justice and State Authority: A Comparative Approach to the Legal Process (1986).

${ }^{45}$ As noted in the introduction to his book, see Oliver Wendell Holmes, THE COMMON LAw 5 (New Brunswick: Transaction Publishers, 2005) (1881) ("The life of the law has not been logic; it has been experience.") (emphasis added).

${ }^{46}$ Henry J. Abraham, The Judicial Process. An Introductory Analysis of the Courts of the United States, ENGLAND, AND FRANCE 20 (7th ed. 1998).
} 
resistance against authoritarians shown by the courts, for example, in Zimbabwe, Namibia, Uganda, Tanzania, and others, ${ }^{47}$ was not comparable with the completely yielding judiciary in the former colonies of continental Europe. ${ }^{48}$

\section{E. Outlooks: The Judiciary in the Era of Non-Liberal Democracy}

Suppose Europe enters an era of non-liberal democracy, followed by a new authoritarianism. In that case, emphasis will likely be placed on, among other things, weakening the principle of checks and balances in the spirit of the populist thesis that a democratically elected political elite should not be hindered in its attempts to keep all the promises given to the voters. Such an approach will also weaken the judiciary, not only the constitutional courts.

In the view of its opponents, the rule of law "needlessly" slows down the rulers by imposing various restrictions that have to be respected by the executive branch. Critics thus identify the rule of law with decadent values of liberalism. Viktor Orbán, one of the pioneers of a populist, entirely unlimited democracy, holds a clear position in this regard: Liberal values now stand for "corruption, sex and violence." A non-liberal democracy will be founded on collectivist values and the primacy of society over an individual, which can easily also be connected with the "basic" collectivist value-nationalism. As Orbán says:

In other words, the Hungarian nation is not simply a group of individuals but a community that must be organized, reinforced and in fact constructed. And so in this sense the new state that we are constructing in Hungary is an illiberal state, a non-liberal state. It does not reject the fundamental principles of liberalism such as freedom, and I could list a few more, but it does not make this ideology the central element of state organization, but instead includes a different, special, national approach. ${ }^{49}$

The war waged against the established ideology of the rule of law can also be seen in the train of thought of another Central European authoritarian, the leader of the Polish conservatives Jarosław Kaczyński remarked that: "Our aim is to destroy the secret establishment steering our political life, the economy and, in some sense, our social life." 50 The role of the law, lawyers, and judges in this "secret establishment" is crucial. In the skeptical view of Polish conservatives, the law is dominated by politics; it is, in substance, political and the law itself is, therefore, unable to control the politics. ${ }^{51}$ If judges pretend that executive and legislative actions control the means of law, they surrender to an illusion or even self-delusion. In fact, their activity is replacing one kind of politics with another.

This is extremely important for all considerations regarding the law: If it is true that the law is indeed nothing else than poorly disguised politics, then all judicial decision-making, and primarily that of constitutional courts, is merely a better or worse conceived fraud. If all legalistic arguments put forth by the courts are solely a façade concealing the political ambitions of judges, then especially the high courts are bastions of the former regime-the liberal democracy. These ancien régime bastions block the will of the people and need to be destroyed, thus giving way to the

\footnotetext{
${ }^{47}$ Generally known in this regard is, the brutal murder of the President of the Ugandan Supreme Court, Benedict Kiwanuka, by Idi Amin's regime. Cf. Remembering Benedicto Kiwanuka, THE JUdICIARY INSIDER No. 11/2018, http://judiciary.go.ug/files/ publications/JudiciaryInsiderIssue11webversion.pdf.

${ }^{48} C f$. Rachel Ellett, Pathways to Judicial Power in Transitional States: Perspectives from African Courts (2013).

${ }^{49}$ Prime Minister Viktor Orbán’s Speech at the 25th Bálványos Summer Free University and Student Camp, (July 30, 2014), https://hungarianspectrum.org/2014/07/31/viktor-orbans-speech-at-the-xxv-balvanyos-free-summer-university-and-youthcamp-july-26-2014-baile-tusnad-tusnadfurdo/.

${ }^{50}$ Dawid Bunikowski, The Crisis in Poland, Schmittian Questions, and Kaczyński's Political and Legal Philosophy 8-9 (Oct. 18, 2017), https://ssrn.com/abstract=3055443.

${ }^{51}$ For an ideological background of this concept, see $I d$.
} 
people's will as it is represented by the political set that currently controls the parliament and the executive branch.

The fact that authoritarian politicians in this region have attacked the constitutional courts, or high courts in general, with such a vengeance, is no accident. Democratic institutions in Central and Eastern Europe are generally weaker than their counterparts in Western Europe. As Slovenian academic Bojan Bugarič has noted, "Western democracies can cope more successfully with various attacks on their liberal institutions because their courts, media, human rights organizations, and ombudsmen have a longer and better-developed tradition of independence and professionalism." ${ }^{52}$ If these institutions in Central and Eastern Europe are generally weaker and less developed, then their decay and onset of various proto-authoritarian tendencies seem unavoidable.

The key reason for the potential decay of judicial independence lies in the apparent indifference to the values of liberal democracy and the rule of law in our region. ${ }^{53}$ Moreover, especially in the 1990s, liberal democracy compromised itself for its blind admiration of neo-liberalism, an economistic ideology, which in many ways merely mirrors the previous materialist approach of real socialism. ${ }^{54}$ The fatigue from the current model of democracy and nostalgia from a predictable "good" past further weakened institutions protecting the rule of law, including the judicial institutions. In this atmosphere, constitutional and other courts stand just a minimal chance to resist the onset of authoritarianism. Constitutional courts can hardly stand as "sole soldiers in the field," defending the rule of law against oncoming autocrats.

The initial attack against the independence of the judiciary can take various forms. Attempts at direct interference, legislative changes such as abolishing courts, and restricting of their competence are not very likely in this regard. For example, the powers of the Constitutional Court have been somewhat limited in Hungary in recent years. ${ }^{55}$ From the ranks of harsher measures, a mere failure to respect judicial decisions is more likely. This is what happened in Poland starting in the autumn of 2015, when the Government ignored key judgments of the Constitutional Tribunal until the new government in power got the staffing of the Tribunal under its control in December 2016. Since then, in contrast, common judges commit a disciplinary offense by failing to respect its decisions. ${ }^{56}$ Much more likely are the finer mechanisms, such as shortening of judges' mandates, early retirement, amending procedural regulations to restrict of access to courts, removing the court presidents and their replacement by presidents who are loyal to the new regime, which typically took place in Czechoslovakia after 1948 and also after 1968, or in Poland after 2017.

Even finer interventions, which are less prone to criticism, might include "dilution" of the staff of the courts by appointing politically checked outsiders as has been the case in a short-lived attempt to create a new system of the administrative judiciary in Hungary in $2019^{57}$ or in Poland-reinforcement of the Supreme Court's personnel following the preceding purges in 2018. Newcomers can outnumber the old judges in the entire system, or it might be sufficient

\footnotetext{
${ }^{52}$ Bojan Bugarič, A Crisis of Constitutional Democracy in Post-Communist Europe: "Lands In-Between" Democracy and Authoritarianism, 13 INT'L J. Const. L. 219-45 (2015).

${ }^{53} \mathrm{It}$ is interesting, however, that there was a visible resistance to attacks in Poland aimed against the Constitutional Tribunal and general courts. Cf. Paweł Skuczyńśki, The Attitudes of Lawyers Towards the Constitutional Crisis and the Independence of the Judiciary, in The Limits of Judicial INDEPENDENCE? 149-66 (G. Borkowski ed., 2016).

${ }^{54}$ See this excellent reflection in Polish legal scholarship: Adam Sulikowski, Government of Judges and Neoliberal Ideology, in LaW and Critique in Central Europe: Questioning the Past, Resisting the Present 16-31 (R. Mańko, C. Cercel \& A. Sulikowski eds., 2016).

${ }^{55} \mathrm{Cf}$. Renata Uitz, Can You Tell When an Illiberal Democracy is in the Making-An Appeal to Comparative Constitutional Scholarship from Hungary, 13 INT'L J. CONST. L. 279-300 (2015).

${ }^{56}$ See Christian Davies, Hostile Takeover: How Law and Justice Captured Poland's Courts, Freedom House (May 2018), https://freedomhouse.org/sites/default/files/polandbrieffinal.pdf.

${ }^{57}$ See Venice Commission, Opinion on the Law on Administrative Courts and on the Law on the Entry into Force of the Law on Administrative Courts and Certain Transitional Rules Adopted by the Venice Commission at its 118th Plenary Session (Mar. 15-16, 2019), https://www.venice.coe.int/webforms/documents/default.aspx?pdffile=CDL-AD(2019)004-e. The Hungarian government eventually gave up this reform.
} 
if they just outnumber them in key decision-making bodies, such as the new special chamber of the Polish Supreme Court with its unique power to review any final court ruling rendered over the past two decades. ${ }^{58}$

What can be the result of such an attack on the independence of the judicial branch?

The judiciary in authoritarian regimes can take on many forms. ${ }^{59}$ An extreme form, typical of totalitarian regimes, is a politically completely marginalized judiciary, which has lost a majority of its key powers and has been fully subjected to political control. As an example, one can refer to the socialist judiciary up to 1989 , which comprised neither judicial review of constitutionality of laws - subject to marginal exceptions - nor of administrative courts, empowered to review the legality of acts of the public administration, for example. Within the model of a politically marginalized judiciary, the powers of courts are limited to decision-making in family law and labor law and issues of routine crime; politically sensitive cases are entrusted to different authorities. ${ }^{60}$ Nevertheless, the institutional and factual arrangement of the judicial branch guarantees full dependence of the judiciary on the political regime. Consequently, if a court is exceptionally called on to decide a political or otherwise sensitive issue, like the criminal punishment of dissidents or apolitical cases that are interesting in some way for those in power such as civil disputes of their family members, then those in power will always be able to influence the result of the case, at least at the appellate level. For example, socialist judges were thus vulnerable to pressure exerted by the local party officers - the proverbial telephone justice.

Of course, not even in this judiciary model should one assume that perhaps every court decision is politically influenced. The following comment by Ota Ulč describes the judicial independence in communist Czechoslovakia:

In about ninety per cent of the court agenda there was not the slightest sign of interference in our decision-making. This observation, however, does not warrant the conclusion that some sort of 'ninety per cent judicial independence and integrity' existed. Both the sorry experience with the remaining ten per cent and the awareness that someone might at any time inflict his 'suggestion' upon us, conditioned all our adjudication. ${ }^{61}$

Nonetheless, it does not appear that new totalitarian power would be coming to Europe in the near future. One should rather fear various other forms of authoritarian regimes. I tend to agree with Mark Osiel that courts and judges behave differently in authoritarian and totalitarian regimes. While in totalitarian systems, judges are unable to "engage in a genuine dialogue with executive rulers through critical examination of the regime's most repressive policies," judges in authoritarian regimes "are not the blunt and perfectly pliable instruments of executive power." 62

In other words, on one hand, judges in totalitarian regimes are unable to help citizens in any way in cases where the state power commits injustice unless such judicial remedy is permitted by those in power themselves, even if for reasons of propaganda. On the other hand, while the judiciary in authoritarian regimes lacks de facto the same guarantees of independence as the judiciary in liberal democracies, this does not mean that defense against interference in courts would be futile from the outset. Indeed, it is not the ambition of those in power in authoritarian regimes to control everything the courts do. As a matter of fact, such total control of the judiciary is not even in the interest of a somewhat enlightened autocrat because full control of the state over courts can, for example, hamper the willingness of investors to operate a business in the given country.

\footnotetext{
${ }^{58}$ In detail, see Davies, supra note, at 56.

${ }^{59} \mathrm{Cf}$. Peter H. Solomon, Courts and Judges in Authoritarian Regimes, 60 World Pol. 125, 122-45 (2007).

${ }^{60}$ In details, Cf. Kühn, supra note 3.

${ }^{61}$ Ulč, supra note 19 , at 61 .

${ }^{62}$ Mark J. Osiel, Dialogue with Dictators: Judicial Resistance in Argentina and Brazil, 20 L. \& Soc. INQUIRY 481, 486 (1995).
} 
Courts in authoritarian populist regimes are mostly not fully controlled by the executive branch but are not fully independent of it either. They often have real, albeit legally or factually limited powers. During the military dictatorships in South America, during the late decades of Francoist Spain, 1960s and 1970s, in Russia following the reforms introduced by Tzar Alexander II in the 1860s, in today's Putin's Russia, but also in communist Czechoslovakia during the last several years before the fall of communism - in all these countries, defense against despotism stood at least some chance of success. ${ }^{63}$ The application of the law is often selective, depending on the ambitions of the judges called on to make a decision and their effort to achieve promotion. Of course, a judge who makes repeated decisions going against the establishment's will stands a lesser chance to boost his or her career.

As in Czechoslovakia, courts devoid of any political power, and countries following socialism from the inception of Stalinism to roughly mid-1980s, are thus merely one extreme example of a controlled judiciary. Politics in authoritarian regimes can approach the judiciary differently, including eliminating certain dangerous judicial institutions and restricting administrative and constitutional judiciary.

Nonetheless, abolishment of constitutional courts is not very likely in contemporary regimes. Today's authoritarians are more inventive in this regard than were the communist rulers before 1989. Indeed, they can also make good use of the constitutional judiciary. The legalistic constitutional language has become deeply embedded in the political discourse over the past few decades. The local constitutional tribunal can justify why one should not adhere to the case law of multinational judicial tribunals, for example by referring to the constitutional identity of a legal system. ${ }^{64}$ The relationships between the European Court of Human Rights and the Russian Constitutional Court are a good example, as the Russian court tends to protect the Russian constitutional specificities - constitutional identity-against the requirements of the Strasburg case law. ${ }^{65}$ Another example is the case law of the "captured" Polish Constitutional Tribunal vis-à-vis the Court of Justice. ${ }^{66}$

In any case, the rejection of case law of an international tribunal appears more elegant if supported by a ruling of the national constitutional court than if the same rejection comes from an executive authority of an authoritarian regime. The steps taken by the Polish Constitutional Tribunal since January 2017 are a certain variation, or rather a caricature, of the same. After the Law and Justice party took control, the Polish Tribunal has served basically as a vehicle for the ruling party against the opposition; it has been abolishing laws complicating the government's rule as "unconstitutional." 67

\section{F. Conclusion}

Public trust remains crucial in terms of the judiciary's ability to resist attacks by those in power. On the one hand, the current situation in the Czech Republic is not that bad; according to public

\footnotetext{
${ }^{63}$ On the Latin American dictatorships and their courts, $c f$. id; ANTHONy Pereira, Political (In)Justice: Authoritarianism and the Rule of Law in Brazil, Chile, AND ARgentina (2005). For Spain during the reign of F. Franco, cf. Solomon, supra note 59, at 126 citing further literature. Id. for the Tsarist Russia after 1864. For an absorbing analysis of decision-making by contemporary Russian courts, cf. Aleksei Trochev, Legitimacy, accountability and discretion of the Russian courts. In: PoliTICS AND Legitimacy IN PosT-Soviet Eurasia 121-47 (M. Brusis, J. Ahrens \& M. S. Wessel eds., 2016) (according to the author, in civilian disputes, the plaintiffs have a growing chance to succeed even in disputes against the Russian state, which was something unimaginable at times of communism). For Czechoslovakia, see Kühn, supra note 3.

${ }^{64}$ For the current debate, cf. e.g. Federico Fabbrini \& András Sajó, The Dangers of Constitutional Identity, 25 EUROPEAN L. J. 457-73 (2019).

${ }^{65}$ Aleksei Trochev, The Russian Constitutional Court and the Strasbourg Court: Judicial Pragmatism in a Dual State, in Russia and the European Court of Human Rights: The Strasbourg Effect 125-49 (Lauri Mälksoo \& Wolfgang Benedek eds., 2017).

${ }^{66}$ See the judgment of the Polish Constitutional Tribunal of 14 July 2021, no. P 7/20 (the supremacy of the Polish constitution over EU primary law).

${ }^{67}$ For a detailed description, see Wojciech SAdurski, Poland's Constitutional Breakdown (2019).
} 
opinions, almost sixty percent of citizens trust the Czech judiciary. ${ }^{68}$ However, on the other hand, this support is very fragile. The Czech judiciary has been suffering from many scandals, and trust in it is being impaired by several endless judicial sagas. Although these scandals are an exception from a rule, as the vast majority of proceedings end in a reasonable period of time and their duration, which is very good in the European context, has been decreasing, nevertheless, these cases attract great attention of the media and fundamentally harm the judiciary.

Renowned judges are therefore relatively skeptical. For example, late Jan Vyklický, an honorary President of the Czech Judicial Union stated:

Show me a single recent event in Czech judiciary that would be characterized by moral quality and primarily by its convincing nature, and would thus improve the reputation of the judiciary. We have already become used to not finding anything, just empty words or purpose-driven reactions. ${ }^{69}$

While these sentences were uttered in 2007, they remain absolutely valid even today.

However, not even the Czech judicial system is immune to an orchestrated political campaign, such as the one that occurred in Poland after 2015. A billboard and media campaign against the country's own judiciary, indirectly financed by the Polish executive branch, specifically, by stateowned enterprises, in 2017 and 2018, referred in populist fashion to alleged or actual sins of the judiciary. This was aimed to weaken the public confidence in the judiciary and legitimize a "judicial reform," which was, in fact, more of an attempt at a hostile takeover of courts by the new political set than a reform, in the proper sense of the word..$^{70}$

As argued above, the judiciary in the continental legal culture lacks the conceptual and institutional resources to provide a sufficient defense of a democratic state governed by the rule of law in the long term. The Constitutional Court will not ensure defense either, whatever its strength: as shown by the example of the Polish constitutional crisis from 2015 to 2016, a strong populist government holding a majority in the Parliament can simply ignore judgments of the constitutional tribunal and wait for a change in the personnel of the court, which will be determined by this government itself. ${ }^{71}$

Based on their very substance, constitutional courts limit and check the current parliamentary majority. They are institutions that go against the political majority. Hence the fitting term "counter-majoritarian difficulty." 72 Administrative courts limit executive acts and check the lawfulness of public administration. The constitutional judiciary, as well as the administrative judiciary, thus come into a conflict with non-liberal ideology. Non-liberal leaders emphasize the people's will, albeit expressed in the current political distribution of forces such as direct democracy. Although, it can be considered that direct democracy does not support people who answer the presented questions but rather the person who formulates them. Non-liberal regimes dislike constitutional and administrative courts because they perceive their competencies as inappropriate limitations of democracy. Democracy is based on the will of the people and, therefore, the executive and legislative branches should not be restricted in any way in the unlimited "distribution of the good," according to the then current political division of forces.

Non-liberal regimes are very skeptical towards the nature of interpretation of law, which-in their opinion-is nothing else than pure politics concealed behind a veil of legalistic jargon.

\footnotetext{
${ }^{68}$ In March 2018, judiciary enjoyed trust of fifty-six percent of citizens. For comparison, the army was trusted by sixty-nine percent and the police by sixty-six percent of citizens, while churches by mere twenty-five percent. See Confidence in Selected Public Institutions, CVVM (Mar. 2018), https://cvvm.soc.cas.cz/media/com_form2content/documents/c2/a4580/f9/po180405.pdf.

${ }^{69}$ Jan Vyklický, Etické skomíráni nebo snad probouzení? [Ethical Languishing or Perhaps Awakening?] 9 SOUDCE 2 (2007).

${ }^{70}$ For more details, $C f$. Sadurski, supra note 67.

${ }^{71} I d$.

${ }^{72}$ For more details, see AleXANDer Bickel, The LeAST Dangerous BranCH (1962) and numerous literature following on from this book.
} 
Unfortunately, many court decisions prove non-liberal politicians right. Too often, the courts put their own political views into their decisions, rather than referring only to what is written in law or constitution or what can be derived from these sources of law based on a generally recognized methodology of legal interpretation. However, if the law does not have the potential, for at least partial autonomy, in relation to everyday politics, the ambitions of non-liberals to replace judges with those having opposite political and value opinions, may appear an absolutely legitimate element of promoting democracy.

It is well known that interpretation of the law is a contextual exercise. Therefore, the legal doctrine has a good potential to reduce the uncertainty of the law, structure the arguments and generally indicate certain rules of priority in case of a conflict of interpretation rules, which, however, will never be without exceptions. ${ }^{73}$ Nonetheless, if we give up on the idea that the law is capable of being at least partially an autonomous phenomenon, that is capable of limiting the government and parliament relatively independently of the value preferences of the individual judges, a gate will soon be wide open for government of the current political majority which is limited by nothing and noone. Moreover, in this understanding, it is, in fact, only logical if the currently ruling majority always transforms a judiciary and its personnel to its liking. Judges of general courts would then not be appointed for an indefinite term, or rather until some fixed time, typically seventy years of age, but only for the period when they enjoy the trust of the ruling political machinery.

From this viewpoint, non-liberal democracy is, in fact, merely a transient phenomenon because, sooner or later, this will no longer be a democracy at all. If the ruling power is not limited in its activities in any way, it becomes completely unclear why it should let its own political support be repeatedly tested in democratic elections. Such unlimited political power will naturally get an appetite for adapting the election rules to suit it or modify the media environment to its own benefit. If we admit this, we will have to relive our recent history, even if with a different ideology, different political arrangements, and different actors.

\footnotetext{
${ }^{73}$ Cf. e.g., Zdenek Kühn, Formalistic and Non-formalistic Strategies of Central European Justice after 1989, in THE JUDICIAL OpINION, 431-44 (L. Tichý, P. Holländer \& A. Bruns eds., 1st ed. 2011).
} 